\title{
Nový halštatský areál Suchohrdly „U Hájkova mlýna” v mikroregionálním kontextu
}

\section{The new Hallstatt Period site at Suchohrdly "U Hájkova mlýna" in micro-regional context}

\section{Richard Bíško / Kateřina Červená / Peter Milo / Jan Petřík}

\begin{abstract}
Abstrakt
Cílem článku je představit novou lokalitu „U Hájkova mlýna” (k. ú. Suchohrdly), která byla objevena v roce 2011 v rámci ověřování prediktivního modelu výšinných poloh na jihozápadní Moravě. V rámci konkretizace a začlenění nového areálu do sídlištní struktury bylo na lokalitě postupně aplikováno široké spektrum nedestruktivních nebo málo destruktivních postupů (mikrosondáže, magnetometrická prospekce, průzkum detektorem kovu). Vzhledem k povaze získaného materiálu, jehož drtivá většina odpovídá pozdnímu halštatu, Ize na lokalitě předpokládat celkovou dominanci tohoto období (nejedná se však o lokalitu monokulturní). Zhodnocení výsledků prospekce je v př́spěvku věnováno nejvíce prostoru. Část je ovšem věnována i problematice vzájemného vztahu mezi dalšími halštatskými lokalitami v blízkém okolí (trat' "Vinohrady", "Sutny" atd.).
\end{abstract}

\section{Klíčová slova}

sídlištní areál, geofyzikální měření, mikrosondáže, průzkum detektorem kovu, doba halštatská, mikroregion

\begin{abstract}
The aim of the article is to introduce a new site "U Hájkova mlýna" (cadastral district of Suchohrdly), which was discovered in 2011 during verification of a predictive model of hilltop sites in Southwest Moravia. In order to specify the new site and set it into the context of settlement structure, a wide spectrum of non-destructive or little destructive methods were gradually applied to the locality (microprobes, magnetometric survey, metal detector survey). Considering the character of the material obtained, which for the most part corresponds to the Late Hallstatt Period, the site can be supposed to have been dominantly occupied in that period (but it is not a monocultural locality). Most attention in the paper is paid to the evaluation of results of the survey. One part, however, is also dealing with the problem of mutual relationship between the other Hallstatt Period sites in close neighbourhood (the sites of "Vinohrady", "Sutny", etc.).
\end{abstract}

\section{Keywords}

settlement area, geophysical measurement, microprobes, metal detector survey, Hallstatt Period, microregion

Tento článek je výstupem projektu NAKI Historické využívání krajiny Českomoravské vrchoviny v pravěku a středověku reg. č. DF13P01OVV005. 


\section{1. Úvod}

Rozsáhlý prostor Tvořihrázského lesa a jeho nejbližšího okolí přitahuje pozornost archeologů již od 20. let 20. století. Postupně zde bylo provedeno několik terénních výkopů dokládající intenzivní osídlení nejen v období halštatu (Vildomec 1954; Podborský 1972, 47). Největší zájem byl věnován nejnápadnějším pozůstatkům, především mohylovitým útvarům a destrukcím hradby na lokalitě „Starý zámek“ (k. ú Suchohrdly; Podborský 1972, 47). Teprve v posledních letech se provádí systematická prospekce motivovaná především rozsáhlou lesní těžbou (Šabatová 2011; 2013). K těmto aktivitám lze přiřadit revizní odkryv výše zmíněného hradiska, jenž byl podpořen četnými moderními analytickými postupy a detailním průzkumem lokality (Šabatová 2008; 2009; 2010). Nedestruktivními metodami bylo dokumentováno také hradisko „Deblínek“ (k. ú. Suchohrdly; Bíško - Milo Petrrík 2013).

$\mathrm{V}$ přilehlém zemědělsky dlouhodobě obdělávaném regionu se nachází polykulturní lokality „Sutny“ (k. ú. Kyjovice) a „Vinohrady“ (k. ú Těšetice), které byly z hlediska halštatu souhrnně zpracovány (Golec 2003; Podborský a kol. 2005).

Přestože by se mohlo zdát, že archeologický potenciál regionu, který je dlouhodobě a intenzivně sledován, musí být vyčerpán, není tomu tak. V rámci ověřování prediktivního modelu výšinných areálů v povodí ř́čcky Únanovky se podařilo doplnit velké množství informací do celkové mozaiky pravěkých lokalit v této oblasti. Novým objevem byla halštatská situace na pravém břehu Únanovky v trati „U Hájkova mlýna“ (k. ú. Suchohrdly, ppč. 622/81; Bíško 2011).

Předkládaný článek si klade za cíl především prezentaci výsledků nedestruktivního nebo málo destruktivního výzkumu na lokalitě „U Hájkova mlýna“. Vzhledem k úzké provázanosti $\mathrm{k}$ dalším halštatským areálům blízkého okolí se nabízí možnost srovnání a otázka celkového začlenění do mikroregionální struktury. Prostor lokality totiž spadá do tzv. halštatského mikroregionu Těšetice. Nabízí se tedy otázka, $\mathrm{k}$ jakému druhu areálu daná lokalita patří?

Termín halštatský mikroregion $\mathrm{v}$ povodí Únanovky zavedl jako první M. Golec. Jde o úzký pás táhnoucí se podél říčky, kde vyvíjeli různé druhy činnosti (především sídlištní) nositelé horákovské kultury. Nelze přitom mluvit o jednotlivých lokalitách, ale o modelu osídlení krajiny bez sídliště tzn. trvale obydlenou krajinu s kumulacemi staveb, kde probíhaly posuny obyvatelstva v rámci mikroregionu. Tato poloha, nacházející se poblíž vodního zdroje, je vhodná pro rozvinutí zemědělsko-pasteveckého způsobu života. Volný neosídlený prostor severně od pásu osídlení byl vhodný pro umístění polí a také nalezená zuhelnatělá obilná zrna poukazují na zemědělský charakter osady (Golec 2003, 11-12).

\section{Charakteristika prostředí}

Zmiňovaný region se nachází v geomorfologickém okrsku Výrovická pahorkatina (jihovýchodní část Znojemské pahorkatiny), která je charakteristická soustavou plochých hřbetů, náhorních rovin a plochých protáhlých sníženin. Oblast je v pravidelných liniích od západu k východu proříznutá místy širokými ale zároveň velice hlubokými údolími řek a říček (Jevišovka, Únanovka atd.) napájených četnými často sezónními přítoky. Údolí Únanovky ústí nedaleko na východ od lokality do Dyjsko-svrateckého úvalu.

Z geologického hlediska je oblast tvořená žulami a granodiority dyjského masivu a ostrůvky miocenních usazenin. Vegetace je tvořena dubovými pařezinami a habrem, méně potom borovice a akátiny (Demek - Mackovčin 2006, 504). Podle antrakologických analýz uhlíků z halštatských objektů zkoumaných na lokalitě 
„Sutny“ E. Opravilem (1961) je patrné, že v této periodě byl nejrozšířenějším typem lesního porostu společenstvo Quercion pubescentis (bazifilní teplomilné doubravy). Pro vývoj údolní nivy jsou typické oscilace v sedimentárním záznamu, odrážejí dynamiku nivy a efekt vodní eroze v regionu spolu s postupnými změnami vegetace a narůstajícím vlivem člověka (Petřík a kol. 2015, 407).

Samotná lokalita „U Hájkova mlýna“ je situována na výraznou plošinu (amfiteatrální stupeň) vhloubenou do svahu pravého břehu řičky Únanovky v nadmořské výšce 250-260 m n. m (relativní převýšení cca $30 \mathrm{~m}$ ). V současné době je terén značně ovlivněn zatopením údolí přehradní nádrží Těšetice. Výstavba přehrady nezasáhla prostor několika malých ostrožen, na kterých je lokalita situována. Celý komplex je asi $500 \mathrm{~m}$ dlouhý a $180 \mathrm{~m}$ široký, tvořený výchozy granodioritů a kvarcdioritů, které jsou oddělené soustavou strží, jejichž dno je vyplněno koluviálními sedimenty. Geneze těchto strží může souviset $\mathrm{s}$ erozí zapř́íčiněnou činností člověka (například úvozové cesty), avšak jejich orientace je pravděpodobně dána prrítomností zlomových struktur v podloží. Plošina směrem na jih stoupá do prudkého kopce směrem na náhorní rovinu v trati „Purkrábka“ (k. ú Suchohrdly). Svými proporcemi se tedy jedná o strategicky výhodně položené místo.

Uzavřený obraz krajiny lemuje rozsáhlý les, jenž si zachoval svůj charakter z předindustriální éry, což je zřetelné na I. i II. vojenském mapování.

\section{Metodika a použité postupy}

Vzhledem k lesnímu prostředí trati „U Hájkova mlýna" bylo jindy široké spektrum nedestruktivních metod značně ochuzeno a nezbyla jiná možnost než jej obohatit o některé málo destruktivní přístupy.

\subsection{Vzorkování objektů a vrstev pomocí sítě mikrosond}

Prospekce formou mikrosondáže sleduje výskyt a rozmístění artefaktů v povrchové vrstvě zeminy formou velmi malých sond či vrypů. Vzhledem ke skutečnosti, že většina zásahů by měla vést až na geologický podklad, je možné zkoumat pouze omezené území, nikoliv celé úseky krajiny. Konečným zjištěním prospekcí mikrosondáží může být pouze základní informace o tom, že v určitém areálu v minulosti probíhala blíže neurčená antropogenní činnost. Jen výjimečně se podaří získat chronologicky citlivý materiál. Důvodem těchto nedostatků je prozkoumání pouze velmi malé části zeminy. Přítomnost terénních reliktů (valy, příkopy atd.) nemusí nutně znamenat pozitivní zjištění pomocí mikrosondáže (Beneš a kol. 2004, 358).

Pro účely vzorkování byly vytvořeny tři geografické čtvercové vrstvy $(\mathrm{B}, \mathrm{P}$ a $\mathrm{Q}$ - označení určené původně pro ověření prediktivního modelu ve smyslu dané skupiny sítě čtverců na jednotlivých vytipovaných místech mikroregionu; Bíško 2011), které se skládaly z různého počtu čtverců o hraně dlouhé $10 \mathrm{~m}$. Vytyčení probíhalo pomocí GPS přístroje (GeoExplorer 6000 GeoXH , kódové korekce), pomocí kterého se podařilo lokalizovat střed každého čtverce. Bud' za pomoci nataženého měřičského pásma mezi středy dvou čtverců, nebo za pomocí kompasu byly určeny světové strany. Pásmo mělo za úkol určit vzdálenost od středu čtverce $(2,5 \mathrm{~m}$ za ideálního předpokladu), jednotlivé mikrosondy tak nemusely být zaměřovány, nebot' jejich geografickou polohu bylo možné určit v GIS. Ve čtyřech bodech světových stran byl následně vytvořen vryp. Velikost mikrosondy odpovídala možnostem kopajícího, ale většinou se pohybovala v rozmezí $30 \times 30 \times 20-30 \mathrm{~cm}$. Dosažení podloží mělo být primární, ve většině případů se to však nepodařilo. Vykopaná zemina se prosívala pomocí drobného síta a získaný materiál 


\begin{tabular}{|l|l|l|c|}
\hline \multicolumn{1}{|c|}{ Druh prospekce } & \multicolumn{1}{|c|}{ Časový rozsah } & \multicolumn{1}{c|}{ Zkoumaný prostor } & Počet prospektorů \\
\hline $\begin{array}{l}\text { Vzorkování vrstev a objektů } \\
\text { pomocí sítě mikrosond }\end{array}$ & duben 2011 & vrstva B & $4-5$ \\
\cline { 2 - 4 } & listopad 2013 & vrstva Q a P & $4-5$ \\
\cline { 2 - 4 } & březen 2014 & vrstva P a B & 5 \\
\cline { 2 - 4 } & listopad 2014 & vrstva B a Q & 3 \\
\hline Geofyzikální prospekce & únor 2014 & plocha A, B a C & 4 \\
\cline { 2 - 4 } & duben 2014 & plocha D a E & 3 detektory \\
\hline
\end{tabular}

Tab. 1. Harmonogram jednotlivých částí prospekce v areálu "U Hájkova mlýna”.

Tab. 1. Schedule of individual parts of the survey in the "U Hájkova mlýna" area.

byl třízen. Veškeré doklady antropogenní činnosti se dokumentovaly.

Cílem při podrobném sondování nebylo pouze získání velkého množství materiálu ale i modelace jeho distribuce. Ukázalo se, že hustota 1 sonda na $25 \mathrm{~m}^{2}$ umožňuje podrobné mapování distribuce artefaktů, na jehož základě lze lokalizovat potencionální archeologické struktury (objekty). K ověření funkčnosti možnosti mapování zahloubených struktur antropogenního původu pomocí husté sítě sond se jednotlivé plochy čtvercové sítě a magnetometrického měření v určitém prostoru překrývají (Obr. 1.). Tímto způsobem je sice možné identifikovat potencionální archeologické struktury, na konkrétní informace o charakteru (rozlišení kontextů, přesnějších rozměrů atd.) jednotlivých objektů je však rozměr mikrosond příliš malý.

Tato část prospekčních metod se projevila jako nejvíce časově nákladná a na lidských zdrojích závislá (viz Tab. 1). V tomto směru nemůže konkurovat geofyzikálním metodám. Nicméně jiná metoda než sondování není v hustě zales- něném terénu uplatnitelná a je rychlejší a ekonomicky výhodnější než klasický destruktivní zásah, mapující navíc celý prostor lokality. Výsledná data (např. Obr. 3.) byla získána interpolací (metoda Topo to Raster v ArcGIS; např Hutchinos 1989) bodů do rastru a zpětnou vektorizací dle určitých rozsahů hodnot (index 30 v násobku váhy a počtu fragmentů). Za potenciální archeologické objekty byly označeny pouze místa s nevyšší koncentrací váhově výrazných keramických fragmentů.

\subsection{Geofyzikální prospekce}

Cílem geofyzikálního průzkumu na poloze „Hájkův mlýn“ bylo lokalizovat podpovrchové archeologické struktury a tím definovat intenzitu a rozsah pravěkých, případně středověkých sídelních aktivit na lokalitě. Uskutečnila se pouze v její odlesněné části. Terénní průzkum byl podniknut ve dvou kampaních na jaře 2014 (Tab. 1). Prozkoumáno bylo pět samostatných úseků

- Obr. 1. Suchohrdly "U Hájkova mlýna”. Rozložení ploch pro geofyzikální měření (A-E), sondovaných čtvercových vrstev (B, Q, P) a detektorového průzkumu.

- Fig. 1. Suchohrdly "U Hájkova mlýna". Distribution of areas for geophysical measurement (A-E), probed square layers $(B, Q, P)$ and detector survey. 


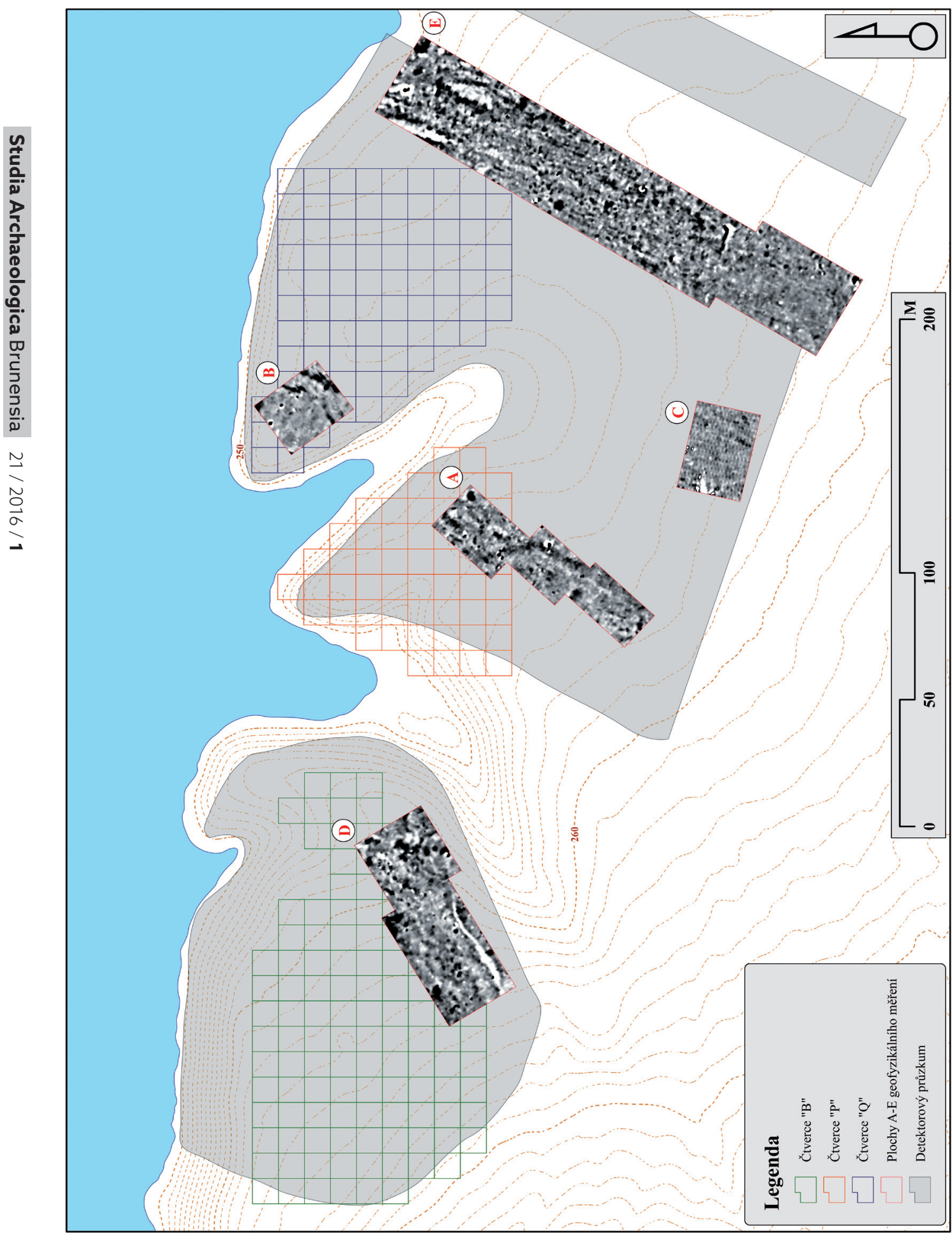


Bíško / Červená / Milo / Petř́k

Nový halštatský areál Suchohrdly „U Hájkova mlýna" v mikroregionálním kontextu

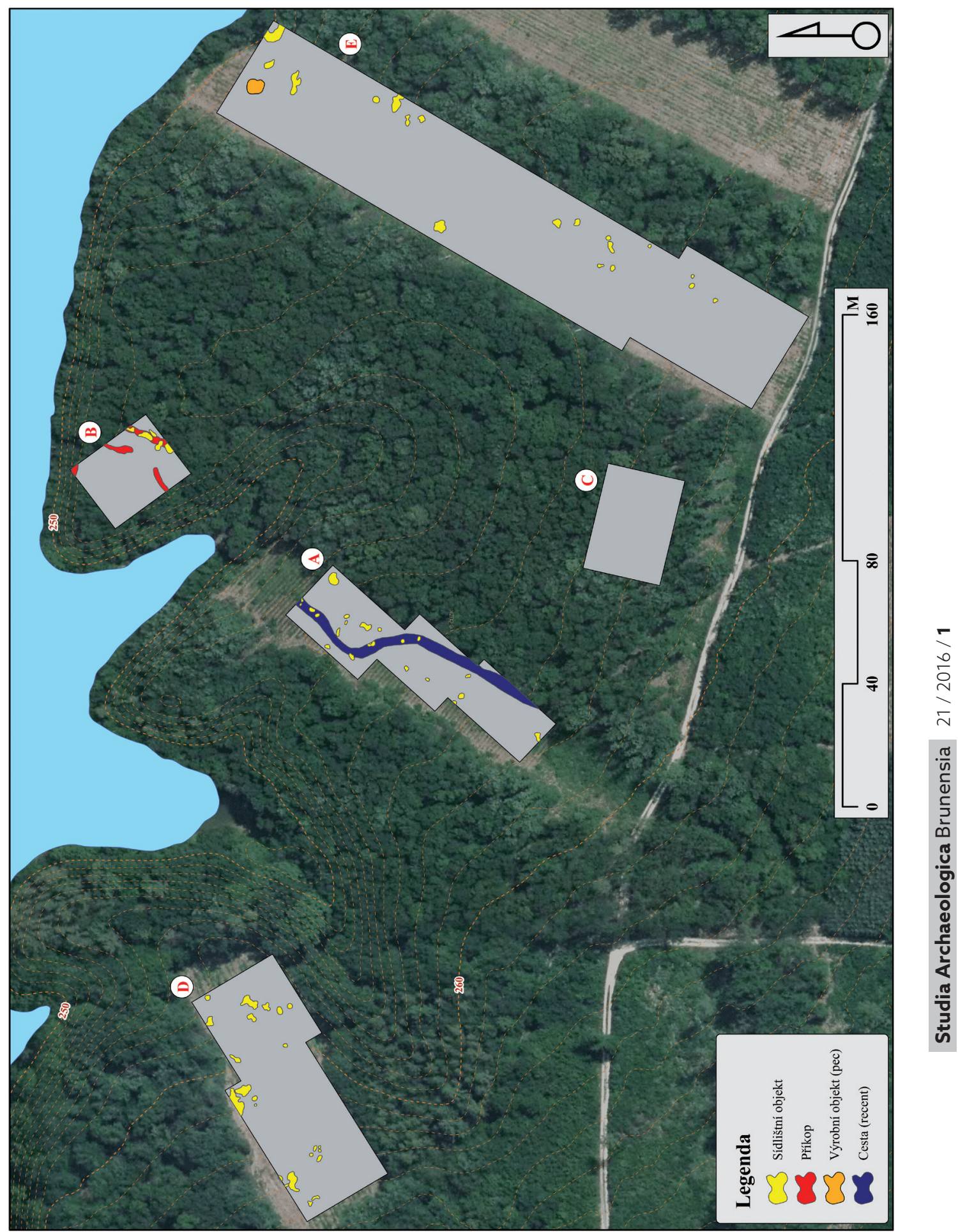


(plochy A až E) o celkové výměře 1,25 ha, situovaných do centrálního prostoru předpokládaného sídlištního areálu, jako i do jeho okrajové, resp. nejisté zóny (Obr. 1).

Při průzkumu archeologických nalezišt sídlištního charakteru nachází mezi geofyzikálními metodami nejširší uplatnění magnetometrie. S využitím magnetické prospekce byly proto zkoumané také jednotlivé segmenty v trati „U Hájkova mlýna“. K dispozici jsme měli fluxgate magnetometr Förster Ferex 4.032 DLG, konfigurovaný jako čtyřsondový gradiometr. Měření probíhalo v síti samostatných nebo na sebe navazujících polygonů se záznamem magnetických hodnot v síti bodů o hustotě $0,25 \times 0,5 \mathrm{~m}$.

\subsection{Detektorový průzkum}

Prospekce pomocí detektoru kovů (XP GOLD MAXX POWER) sloužila především jako ověření prostoru pozitivního na archeologický materiál. Za ideálních okolností probíhá průzkum v předem vytyčené síti, v které je prostor důsledně čištěn od kovového materiálu. Tento způsob ovšem nebyl vzhledem k omezeným personálním kapacitám možný. Lokalitu se tedy nepodařilo prozkoumat zcela, i tak se kladl důraz na systematický lineární postup (Tab. 1) při procházení jednotlivých částí lokality (Obr. 1).

Vzhledem k různým prostorovým a časovým dispozicím jednotlivých částí prospekce nebylo možné (kromě drobného překryvu v případě geofyzikálních ploch a sondážních vrstev) fáze prospekce př́liš koordinovat. Průzkum detektorem kovu na plochách geofyzikálního měření probíhal souběžně s magnetometrickou prospekcí. Absence výsledků geofyziky tedy např. neumožňovala zaměřit se detektorem kovu na jednotlivé feromagnetické anomálie v magnetogramu.

\section{Průběh a výsledky výzkumu}

\subsection{Geofyzikální prospekce a sídlištní struktura}

Geofyzikální průzkum lokalizoval na poloze početné anomálie různého původu (Obr. 2). Severovýchodní část lokality (plocha E) vykazuje značnou míru narušení podpovrchových vrstev a tím pádem i archeologických objektů orbou. Lesnické aktivity tu narušily podložní geologickou vrstvu, která se projevila ve formě výrazných magnetických linií. Tato skutečnost neumožňovala sledovat archeologické situace v plné míře. Na ostatních plochách se již dané rušení výrazněji neprojevilo (výjimku představuje jenom erozní rýha při jižním okraji plochy D) a jsou dobře čitelné. Kromě menšího seskupení kovových předmětů na ploše $\mathrm{C}$ bylo registrováno jen několik málo artefaktů metalického charakteru. U většiny $\mathrm{z}$ nich můžeme předpokládat spíše recentní původ, avšak vyloučit nemůžeme ani archeologické artefakty, které se nepodařilo zaznamenat při průzkumu detektorem kovů. Zmínit je nutné ještě lineární, esovitě prohnutý útvar, probíhající přibližně v směru sever-jih centrální části lokality (plocha A). Charakteristický je mírně pozitivními magnetickými hodnotami a můžeme ho interpretovat jako zaniklou cestu.

Výraznou část magnetických anomálií můžeme připsat pravěkým antropogenním aktivitám. Na výsledném magnetogramu se dá sledovat cca. 70 anomálií, které můžeme interpretovat jako archeologické objekty (Obr. 2). Vzhledem na jejich tvarovou variabilitu od kruhových a oválných až po nepravidelné půdorysy, představují široké spektrum sídlištních jam s rozměry od 1 do $20 \mathrm{~m}^{2}$. Bližší charakter ani původní funkce těchto objektů nám známé nejsou. Při

\Obr. 2. Suchohrdly "U Hájkova mlýna”. Výsledky geofyzikálního měření; interpretace magnetogramu.

4Fig. 2. Suchohrdly "U Hájkova mlýna”. Results of geophysical measurement; interpretation of the magnetogram. 
jedné anomálii ze severovýchodního sektoru lokality (plocha E), vykazující výrazně vysoké magnetické hodnoty, můžeme očekávat přítomnost pece nebo objektu s výrazně propálenými složkami jeho výplně.

$\mathrm{K}$ důležitým zjištěním magnetického průzkumu patří lokalizace lineárních anomálií na výběžku ostrožny nad říčkou Únanovka (plocha B). Na základě interpretace magnetogramu bychom tu mohli předpokládat jednoduchý nebo snad i dvojitý příkopový útvar (šířka 2-3 m), vyčleňující ostrožnu od okolního prostoru. Oba lineamenty tu ale byly zaznamenány jenom v krátkých úsecích. Při jižní anomálii nemůžeme vyloučit, že se nejedná o jeden lineární celek ale několik menších objektů, situovaných bezprostředně vedle sebe. Napovídala by tomu heterogenní povaha magnetických hodnot v rámci linie jako celku. Př́ítomnost fortifikačních prvků na lokalitě proto musí být předmětem dalšího bádání, které se již nezaobejde bez ověřovacího archeologického výzkumu, zaměřeného na jižní šíji ostrožny.

Na základě koncentrací keramických fragmentů a mazanice v jednotlivých částech plochy je možné lokalizovat několik antropogenních struktur. Jejich rozmístění do jisté míry koreluje s magnetometrickým měřením (překryv čtvercové sítě B a měřené plochy D). Překryv je viditelný ve dvou případech. Z hlediska výsledků magnetogramu však není možné rozlišit, zda se jedná o struktury se shluky mazanice a keramiky, nebo pouze o zahloubené objekty bez těchto prvků. V jiných částech sondovaného prostoru, především v případě geofyzikálních anomálií menších rozměrů, není korelace přiliš patrná. Zajímavá je celková absence pozitivních sond ve čtvercové vrstvě $\mathrm{P}$, kde je naproti tomu možné prokázat několik potencionálních objektů zjištěných geofyzikou (Obr. 3).

\subsection{Keramický inventář a mazanice}

Mikrosondážemi v prostoru areálu byla získána keramika především z pozdní doby halštatské a keramika blíže neurčitelná, datovaná rámcově do pravěku. Minimum fragmentů pocházelo ze středověku a novověku. Kromě keramického materiálu byla nalezena mazanice, několik fragmentů kamenné industrie a dva zlomky zviŕrecích kostí, popř. kovové předměty.

Celkově bylo ze tří zkoumaných čtvercových vrstev (B, P, Q) získáno 504 keramických fragmentů o hmotnosti 3118 g. Z toho 280 zlomků o hmotnosti 2044 g bylo možné určit jako (pozdně) halštatské (Tab. 2).

Veškerá keramika získaná mikrosondážemi byla velmi fragmentární, všechny střepy bylo možno zařadit do nejmenší kategorie fragmentu K1: zlomky okraje, hrdla, výdutě a dna (podle Šabatová 2007, 288). Vysoké fragmentarizaci odpovídala i průměrná hmotnost zlomku 7,8 g, obdobně u halštatské keramiky viz Tab. 3.

Značné množství halštatské keramiky obsahovalo jako příměs grafit: 184 zlomků (65\%) o hmotnosti 1433 g (70,1 \%). Grafit se v keramickém těstě objevuje již v období kultury s lineární keramikou, poté až v pozdní době halštatské, pravděpodobně ve stupni HD2 (Golec 2003, 120; Hlava 2008, 196). Tzv. grafitová keramika se neomezuje na určitý region, je součástí homogenního kulturního vývoje období pozdního halštatu. Přidáním grafitu do keramického těsta získává nádoba lepší vlastnosti, zejména menší propustnost, nižší nároky na teplotu a dobu výpalu či vyšší odolnost vưči žáru (Trebsche 2011, 451).

Keramika obsahující grafit byla objevena také při záchranném výzkumu v trati „Sutny“ (k. ú. Kyjovice) a datována do stupně HD2 (Golec 2003, 120). Tato keramika byla poté podrobena

• Obr. 3. Suchohrdly "U Hájkova mlýna". Výsledky geofyzikálního měření a distribuce halštatské keramiky.

- Fig. 3. Suchohrdly "U Hájkova mlýna". Results of geophysical measurement and distribution of Hallstatt Period ceramics. 
Biško / Červená / Milo / Petřík

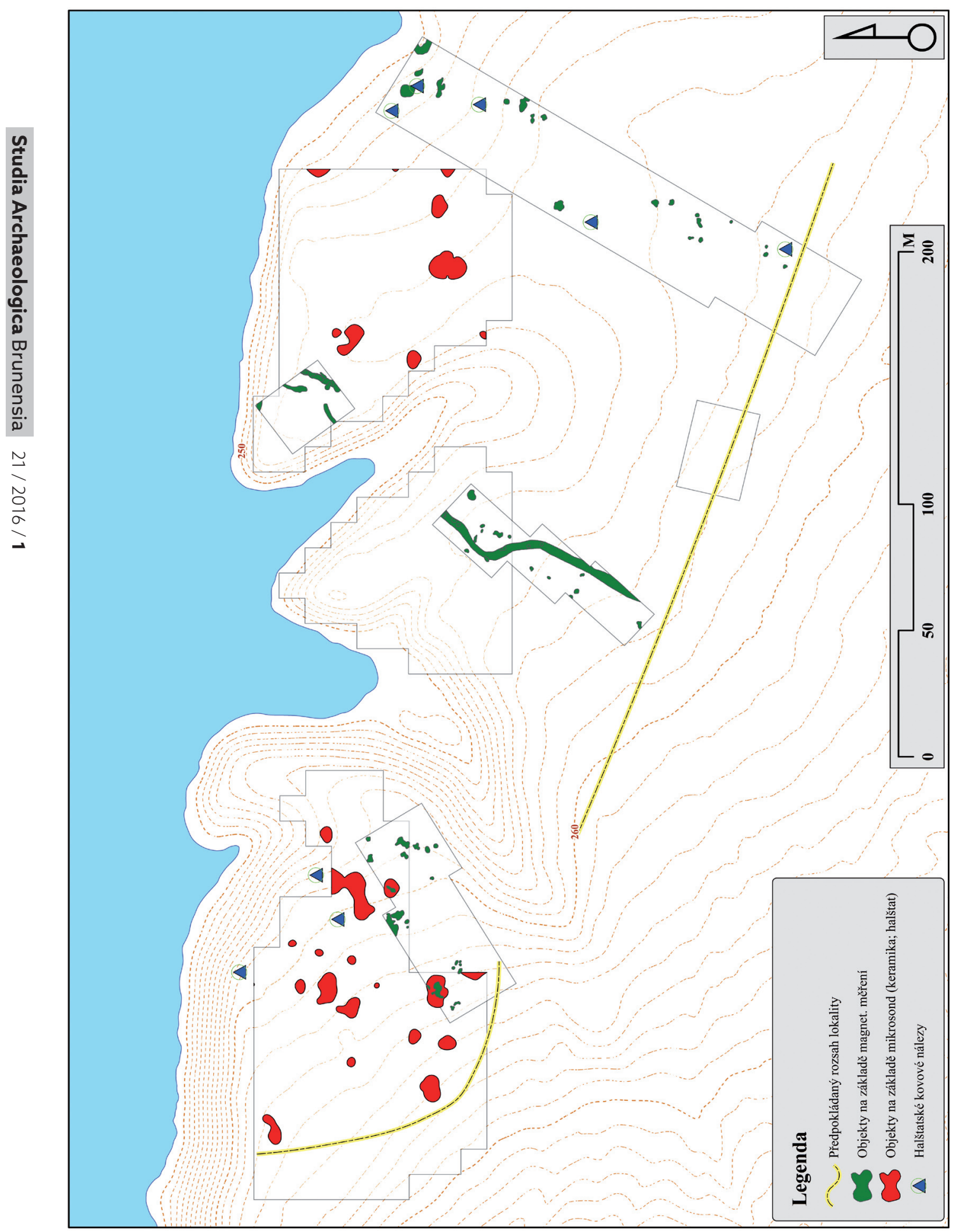




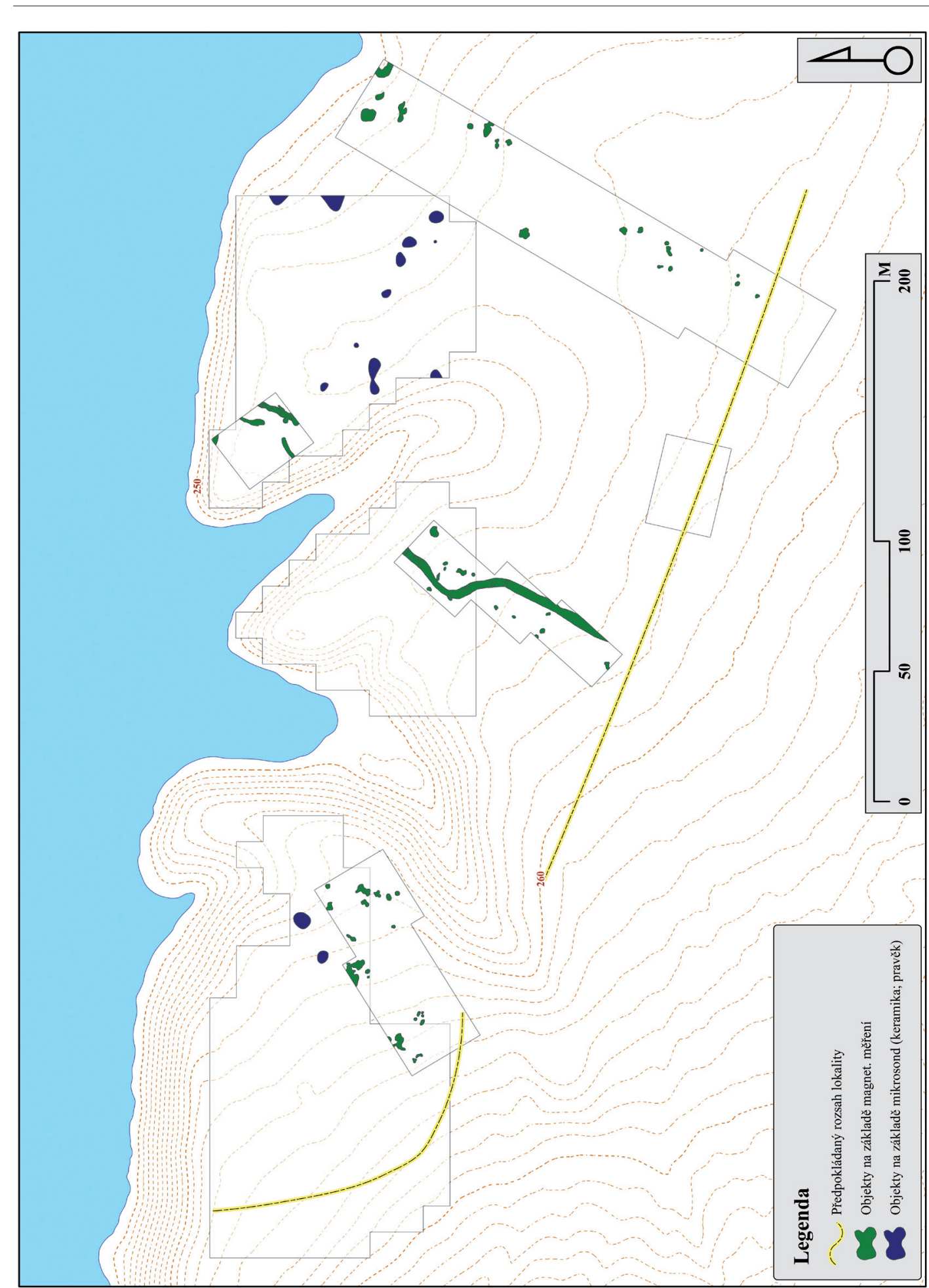


petrografickým analýzám za účelem zjištění provenience grafitu, kdy se ukázalo, že byl využíván grafit z oblasti jižních Čech a nikoli z místních výchozů (Hložek a kol. 2003, 125-128). Na nejednoznačnost výsledků petrografických analýz zkoumající původ grafitu však upozorňuje P. Goláňová v př́ípadě laténské grafitové keramiky z Olomoucka (Goláňová 2014, 138).

Z keramických tvarů bylo možné s určitostí rozeznat pouze zlomky mís a misek se zataženým okrajem. Ze 13 zatažených okrajů byly tři potuhované na vnější a zároveň vnitřní straně, na dalších dvou fragmentech byly zbytky potuhování rozeznány bud' na vnější, nebo vnitř̌ní straně (Obr. 9.10). Vyskytl se také zatažený okraj zdobený úzkým vtuhovaným pásem na vnitřní straně (Obr. 9.8). Ostatní okraje mohly svým tvarem a obsahem grafitu náležet hrncovitým a soudkovitým nádobám, u nichž se předpokládá kuchyňské využití právě díky přítomnosti grafitu, který zlepšuje tepelné vlastnosti keramiky (Golec 2003, 38), nebo k dalším tvarům.

Ze získaného souboru keramiky bylo sedm fragmentů zdobených: kromě zmíněného vtuhovaného pásu se objevil kolek, plastická, vhloubená a rytá výzdoba (Obr. 9.9, 11-14.). Kruhový kolek (důlek) malého průměru byl umístěn na vnější straně na výduti. M. Golec datuje tento typ výzdoby v Těšeticích do stupňů HD1-HD2 (Golec 2003, 100). Tři fragmenty výdutí byly zdobeny plasticky: v jednom prrípadě se pravděpodobně jednalo o část blíže neurčitelné lišty, u dalších dvou šlo o výčnělky. Fragment zdobený vhloubenými důlky lze podle $\mathrm{M}$. Golce a přítomnosti grafitu datovat do pozdní doby halštatské. Plastická a vhloubená výzdoba se (spolu s vtuhováním) vyskytuje nejčastěji,

\begin{tabular}{|l|c|c|c|}
\hline \multicolumn{1}{|c|}{ Datace } & Počet fragmentů & Hmotnost $\mathbf{( g )}$ & počet \\
\hline Halštat & 280 & 2044 & 2 \\
\hline Pravěk - obecný (Obr. 4.) & 214 & 951 & 1 \\
\hline Středověk & 7 & 113 & 1 \\
\hline Novověk & 3 & 10 & 1 \\
\hline
\end{tabular}

Tab. 2. Keramika získaná mikrosondážemi v areálu "U Hájkova mlýna”.

Tab. 2. Pottery obtained by microprobing in the "U Hájkova mlýna" area.

\begin{tabular}{|l|c|}
\hline \multicolumn{2}{|c|}{ Halštatská keramika } \\
\hline Prưměrná hmotnost zlomku (g) & 9 \\
\hline Modus & 1 \\
\hline Medián & 6 \\
\hline Minimální hmotnost zlomku (g) & 1 \\
\hline Maximální hmotnost zlomku (g) & 75 \\
\hline
\end{tabular}

Tab. 3. Charakteristika halštatské keramiky.

Tab. 3. Characteristic of the Hallstatt Period pottery.

4 Obr. 4. Suchohrdly "U Hájkova mlýna". Výsledky geofyzikálního měření a distribuce pravěké (kromě halštatské) keramiky.

4Fig. 4. Suchohrdly "U Hájkova mlýna". Results of geophysical measurement and distribution of prehistoric (except for Hallstatt Period) ceramics. 
v pozdní době halštatské dochází k jejich největší různorodosti (Golec 2003, 54). Posledním zjištěným typem dekoru byly drobné svisle ryté linie na hrdle, v Těšeticích datovány M. Golcem do stupňů HD1-HD2 (Golec 2003, 43).

Dokladem konstrukcí jsou četné nálezy mazanice, které se koncentrovaly především v prostoru čtvercové sítě $B$. Ve většině případů jde o malé kousky kolem $1 \mathrm{~g}$. Nicméně v některých mikrosondách se podařilo lokalizovat velké množství o váze až $300 \mathrm{~g}$ (Obr. 5). Otisk výpletu se dochoval pouze $\mathrm{v}$ jednom př́padě.

\subsection{Kovové artefakty}

Celkově bylo detektorem kovu zachyceno 8 předmětů, které lze téměř s jistotou datovat do průběhu halštatu (Obr. 3).

Části železných spon $(2 \times)$ a hlavice jehlic (2×; Obr. 9.3-4, 6-7) se dochovaly ve velice špatném stavu a pouze fragmentárně.

Pozornost si zasluhuje také zlomek bronzového náramku (Obr. 9.5) a bronzový slitek (DB-DH). Dále pozlacená hadovitě (smyčkovitě) zakroucená záušnice se stylizovanou hlavičkou hada (Obr. 9.1). Má časté paralely ve vekerzugské kultuře v Karpatské kotlině, kde se nachází v častých obměnách (napřr. drátěné ukončené kuželovitou, či zaoblenou hlavičkou). Nejčastěji se nacházejí bronzové, vzácněji ze střríbra a elektronu. Pozlacené byly objeveny např. v Preselanech nad Iplom a Senci. Hadovité ovšem nemají ve skytské kultuře časté paralely. Záušnici lze absolutně datovat do konce 6. století př. n. 1. (Novotná - Novotný 1990, 115-117). Jinou alternativou východního šperku může být další zakroucená záušnice (Obr. 9.2), tentokrát se pozlacený plech na bronzovém základě nezachoval, nebo nebyl aplikován.
Zbytek kovových předmětů nelze konkrétněji datovat, případně se jedná o vrcholně středověké a novověké artefakty.

\section{Diskuze}

$\mathrm{Na}$ základě výsledků magnetické prospekce a sond můžeme na lokalitě předpokládat rozptýlený typ osídlení v celém prostoru plošiny. Vzhledem k omezené velikosti a roztř́šštěnosti zkoumané plochy není možné vyslovit k vnitřnímu rozmístění osídlení jednoznačné závěry. Koncentrace objektů by mohly naznačovat existenci menších sídlištních celků. Archeologické objekty se koncentrují především v severní části zkoumaného areálu, na hraně plošiny nad ř́ičkou Únanovkou. Jižním směrem počet sídlištních objektů klesá a na jižním okraji zkoumané plochy, kde se nachází mírný svah, již můžeme konstatovat jejich celkovou absenci. Hranice sídlištního areálu tedy byla dosažena. Toto zjištění odpovídá i rozložení halštatských aktivit na severním břehu, které má pevnou vazbu na vodní tok (Golec 2003, 147-148). Přesná determinace jednotlivých lokalizovaných objektů není prakticky možná. Geofyzikální průzkum sice je schopen do určité míry a za ideálních předpokladů zjistit funkci naměřené anomálie (např. v prrípadě výrobního objektu v severní části plochy E), ale pouze pokud jeho tvar a výplň jsou natolik charakteristické, že se výrazně odlišují od ostatních objektů.

Podobné spektrum sídelních struktur jako na lokalitě „U Hájkova mlýna“ se pomocí geofyzikálního průzkumu již podařilo identifikovat také na hradiscích „Deblínek“ a „Starý zámek“. Vedle magneticky nevýrazných sídlištních jam se zde vyskytují také objekty s výrazně vy̌̌šími magnetickými hodnotami výplní (žrejmě

- Obr. 5. Suchohrdly "U Hájkova mlýna". Výsledky geofyzikálního měěení a distribuce mazanice.

• Fig. 5. Suchohrdly "U Hájkova mlýna". Results of geophysical measurement and distribution of clay daub. 
Bíško / Červená / Milo / Petřík

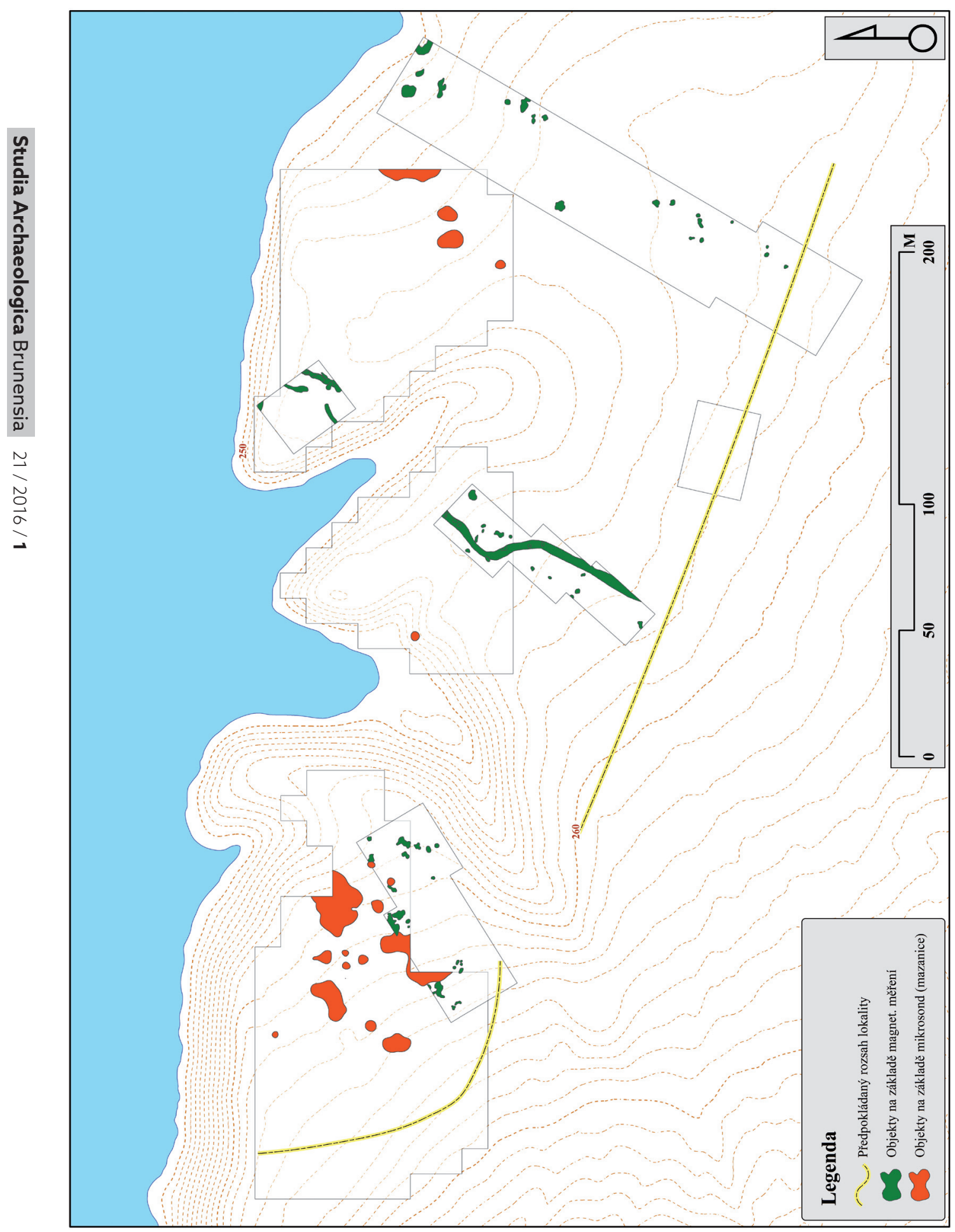




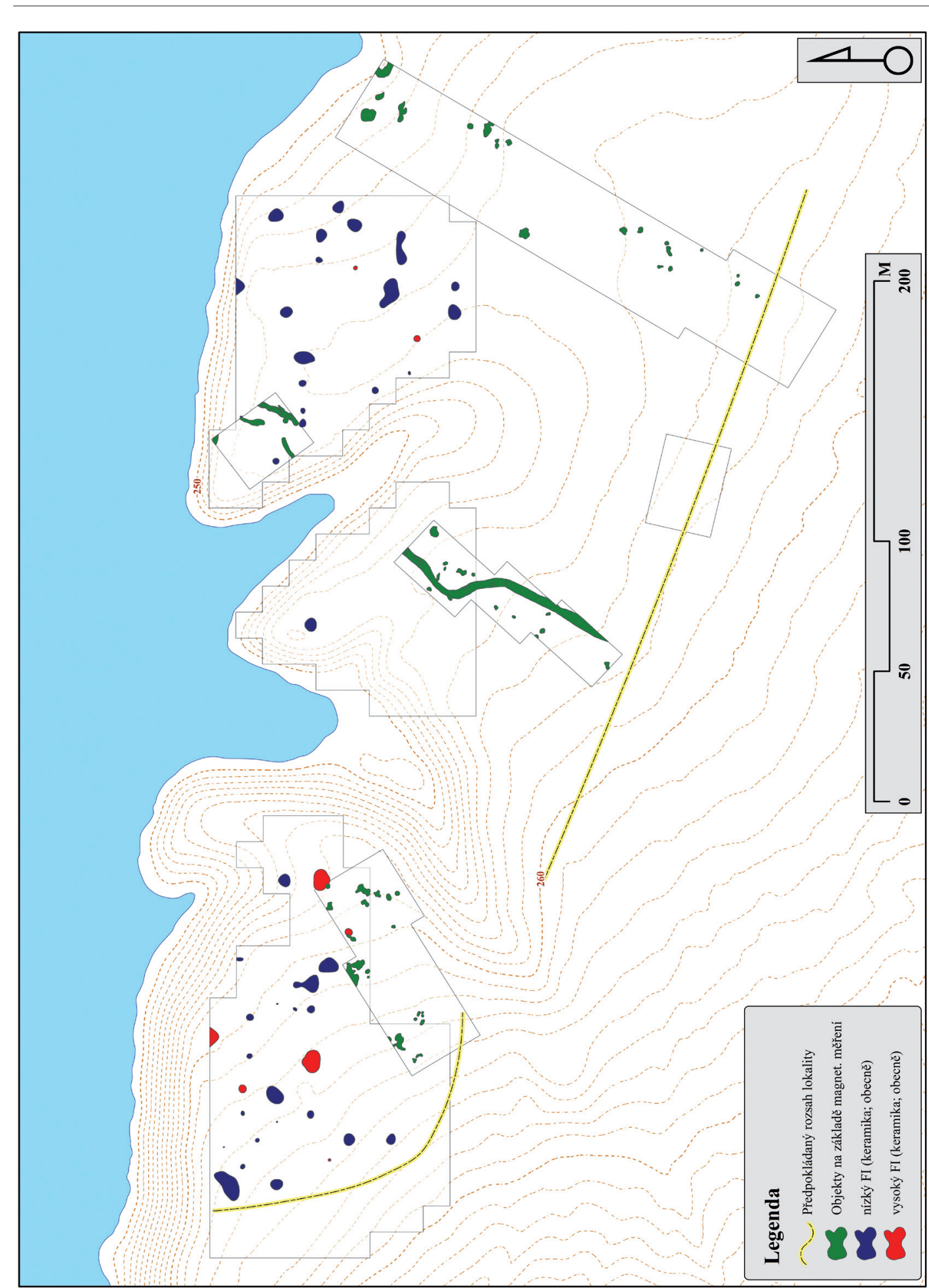


propálených struktur) a lineární útvary fortifikačního charakteru (Bíško - Milo - Petř́ík 2013). Určit funkční a chronologické zařazení jednotlivých objektů je ale pouze na základě geofyzikálních dat dosti obtížné, vzhledem ke skutečnosti, že se jedná o objekty běžné téměř po celý pravěk.

Mnohem lepší interpretační možnosti nabízí lokalita „Sutny“. Ohledně kulturního zařazení magnetických anomálií se zde můžeme spolehnout na tvarovou shodu jednotlivých anomálií $\mathrm{s}$ archeologicky zkoumanými a datovanými objekty (např. exploatační jámy kultury s lineární keramikou a lengyelské kultury; Milo 2013).

Pro mladší období pravěku však typické struktury chybí a rozsah osídlení v tomto časovém úseku se proto ani na lokalitě „Sutny“ jednoznačně určit nedá. Nápadná je však koncentrace menších jam v jižní části lokality, tedy podél vodního toku Únanovky. Bezprostředně jihovýchodně od plochy geofyzikálního průzkumu byly při záchranném archeologickém výzkumu odkryty četné sídlištní objekty, tvarově a rozměrově podobné zjištěným magnetickým anomáliím. Datované jsou především do doby bronzové a halštatu (Podborský a kol. 2005, 171-218, Obr. 159). Můžeme se proto domnívat, že velká část v jižní části lokality identifikovaných anomálií přísluší do období, kdy byl pro sídlištní aktivity intenzivně využíván i protilehlý břeh Únanovky v poloze „U Hájkova mlýna“.

Jak již bylo zmíněno výše, získaný keramický inventár vykazoval vysokou míru fragmentárnosti. Jen velmi malé množství zlomků přesahovalo hmotnost $10 \mathrm{~g}$. Tato skutečnost může být způsobena několika faktory, které v zásadě ovlivňují dochování nádoby.

Mikrosondami byla nejčastěji narušena pouze humusovitá vrstva převážně do hloubky oko- lo $20 \mathrm{~cm}$. V lesním prostředí se obecně velmi špatně zachovávají větší kusy keramiky. Je to způsobeno především bioturbací živočichů, růstem stromů, jejich kořeny atd. Dubovo-habrové lesy na podkladě vyvřelých hornin vytvářejí velmi kyselé prostředí.

Složku podobnou charakteristice kulturní vrstvy se nepodařilo identifikovat. V tomto případě je spíše vhodné označit narušovanou jednotku jako plně vyvinutou tmavou lesní půdu, ve které jsou rozptýleny artefakty. Kulturní vrstva v obecném pojetí (např. Ernée 2008) se nedochovala (případně pouze reziduálně) vlivem morfologie terénu, vlivu vegetace, eroze a pozdějších antropogenních aktivit (úvozy zvětšující erozi, odlesnění).

Geologie a geomorfologie lokality hraje v tomto smyslu důležitou roli. Skalní výchozy a sklon terénu způsobují, že celý prostor je ovlivněn erozí, což je patrné i na charakteru půd, které jsou většinou kamenité a bez horizontů dosvědčujících delší genezi. Vzhledem k přítomnosti rozsáhlých erozních strží lze předpokládat, že určitá část archeologických kontextů mohla podlehnout degradaci. Výplň těchto strží a především pak výplavové kužely na dně údolí (v přehradě) tak zřejmě mohou obsahovat i relikty artefakti̊ a kulturních vrstev z prostoru lokality nad údolím. Tento jev není pro lokality na exponovaných místech neobvyklý a byl již diskutován v souvislosti s absencí pravěkých výšinných lokalit v některých regionech České republiky (John 2002).

Svahové procesy také zásadně ovlivňují dochování keramiky. Ve východní části lokality je terén relativně rovný, oproti západní části plošiny, kde se sklon svahu pohybuje až okolo $7^{\circ}$. Lze také pozorovat určitý rozdíl ve fragmentárním indexu (vysoký index představuje velké

4Obr. 6. Suchohrdly "U Hájkova mlýna". Distribuce fragmentárního indexu; modře nízká, červeně vysoká fragmentárnost.

4Fig. 6. Suchohrdly "U Hájkova mlýna". Distribution of fragmentation index; low fragmentation in blue, high fragmentation in red. 
množství malých zlomků s nízkou hmotností). Zatímco ve svahu v západní části je výskyt koncentrací s vysokým indexem oproti východní části častější, u nízkého indexu je tomu spíše opačně (Obr. 6.).

Značnou fragmentárnost ale mohou způsobovat i blíže nespecifikované jevy, kterým nebylo možné věnovat větší pozornost (např. povaha a funkce zjištěných objektů, materiál a typ výpalu nádob, způsob užívání artefaktů a manipulace s odpadem; Kuna - Němcová a kol. 2012, 183).

Velmi důležité je určit, o jaký druh areálu se v př́ípadě lokality „U Hájkova mlýna“ jedná. Vzhledem k výzdobě keramiky, častému výskytu mazanice a celkové blízkosti dalších halštatských komponent klasického sídlištního charakteru (trat' „Sutny“ a „Vinohrady“) je možné lokalitu chápat jako součást silně provázané množiny prvků-lokalit halštatského mikroregionu (Obr. 7). Celková povaha získaných informací je oproti „Sutnám“ a Vinohradům však i rozdílná. Nabízí se tedy otázka, zda je možné vztáhnout definici zemědělsko - pasteveckého mikroregionu i na tento areál.

1) Plošina (vhloubený stupeň), na kterou je lokalita situována, není příliš rozsáhlá (cca 8 ha). Především ji ze všech stran obklopují geomorfologické prvky, které nejsou pro pěstování plodin ideální. Na západě a jihu se nachází prudký svah, který výrazně stoupá do náhorní plošiny Tvořihrázského lesa. Na severu a severovýchodě ohraničuje areál hrana plošiny (např. Obr. 7.). Další omezení v rámci zemědělského využití prostor zřejmě nemá.

2) Důležitým zjištěním je jistě potenciální přítomnost prríkopu při ploše B. Pro pozdní dobu halštatskou (od stupně HD2) je převládající opevňování výšinných, často menších poloh na ostrožnách (Golec 2003, 140; Parma 2001, 107; Podborský 1970, 11, 14). Několik příkladů můžeme najít ve velmi blízkém okolí, ačkoliv se (vzhledem ke stavu výzkumu) převážně jedná o vždy dochovaný nadzemní relikt (val, viditelný příkop). Dochovaný př́kop můžeme najít napřr. na lokalitě „Skalka“ (k. ú. Bezkov; Vokáč 2004, 258), „Deblínek“ (k. ú. Suchohrdly - ačkoliv je př́kop obecně datován do pozdní doby bronzové; Vokáč 2004, 259-260), „Palliardiho hradisko“ (k. ú Vysočany; Podborský 1966, 128-131). Destrukce hradby je evidována na lokalitách „Smoha“ (k. ú. Bezkov; Podborský 1965, 135), „Turecký kopec“ (k. ú. Hornice; Bláha 1977, 46) a „U cihelny“ (k. ú Štítary; Vokáč 2004, 258).

Za relativně nové zjištění lze považovat několikanásobný příkop na ostrožně „Načeraticko“ (k. ú. Dyje), který byl detekován pomocí magnetometrického měření. Jeho datování do období halštatu však není jisté (Bíško 2011, 59).

Případně se nemusí přímo jednat o strukturovaný fortifikační prvek (šířka 2-3 m), ale běžné ohrazení, ke kterým máme na lokalitách jižní Moravy také četné příklady. Nejblíže v trati „Sutny“, kde je žlabu přikládána spíše kultovní než praktická funkce. Datování je již tradičně problematické (Podborský a kol. 2005, 216).

Lokalitu „U Hájkova mlýna“ z celkového pohledu nelze chápat jako typický výšinný areál, ačkoliv má řadu prvků, které jej charakterizují. Jak ovšem dokládá příklad lokality „Hradisko“ (k. ú. Jaroměřice nad Rokytnou), která je situována z geomorfologického hlediska na velmi podobný terénní prvek (Čižmář 1999), není opevňování malých ostrožen vždy nutným pravidlem.

3) Kromě již zmíněné vysoké míry fragmentárnosti keramiky (Obr. 8), je nejnápadnějším rozdílem častá přítomnost grafitu v keramickém

- Obr. 7. Halštatský mikroregion Těšetice.

- Fig. 7. The Hallstatt microregion of Těšetice. 


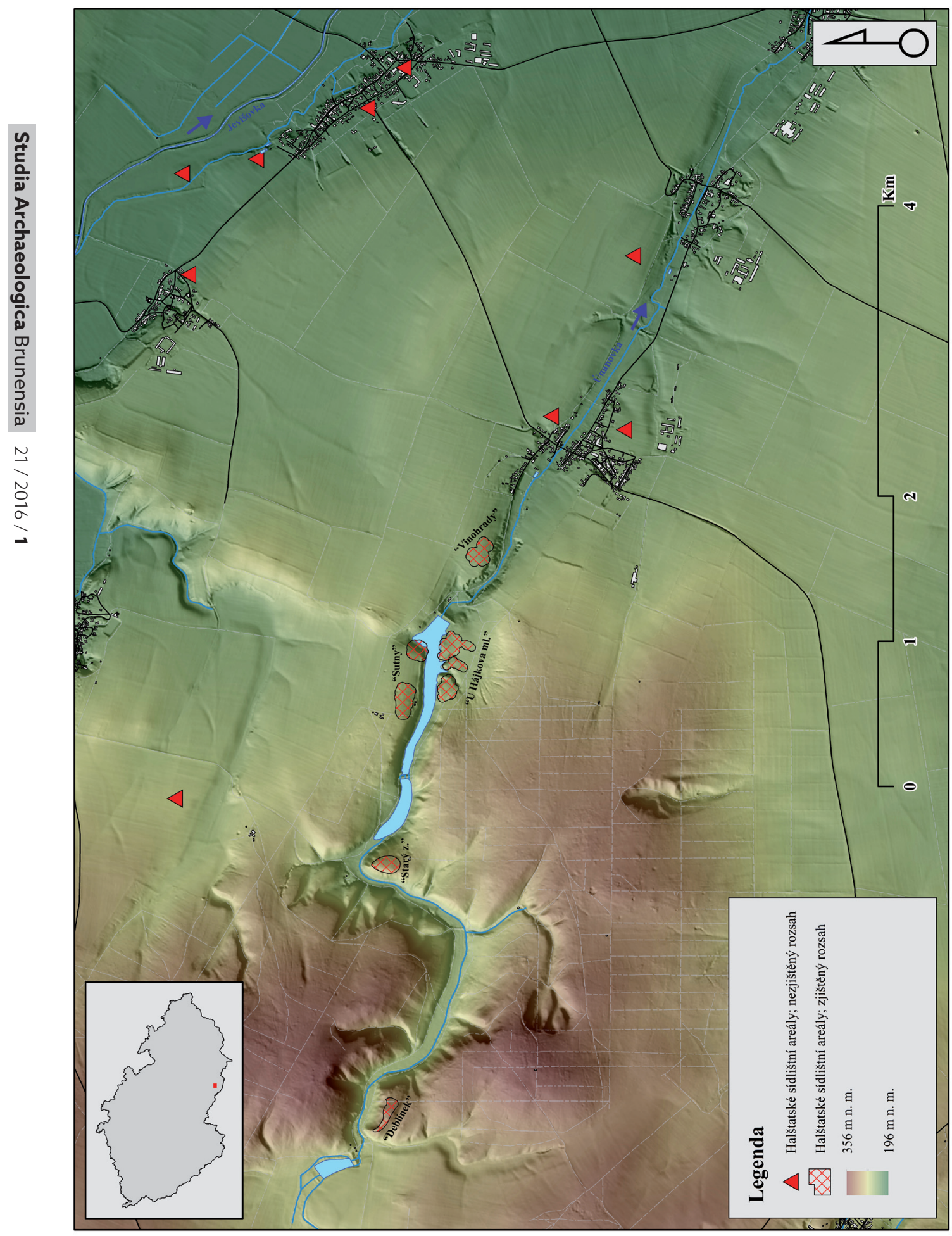




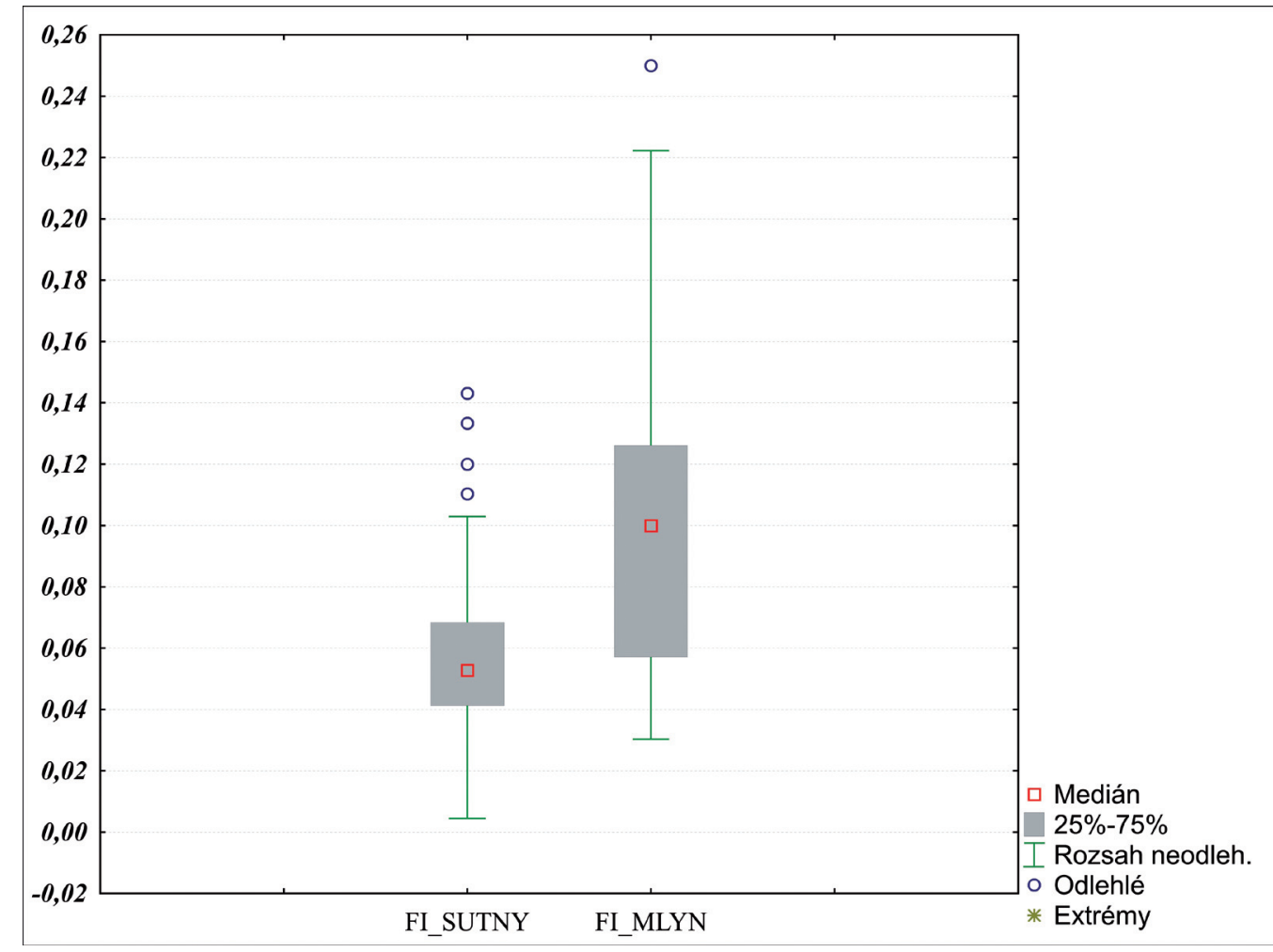

Obr. 8. Porovnání fragmentarizace keramiky z keramických koncentrací na lokalitě "U Hájkova mlýna" a keramiky z objektů na lokalitě "Sutny".

Fig. 8. Comparison between the fragmentation of pottery from ceramic concentrations at "U Hájkova mlýna" site and pottery from features at "Sutny" site

těstě na rozdíl od materiálu z pozdně halštatského osídlení na „Sutnách“, kde grafitová keramika tvořila pouze $0,15 \%$ celkového souboru (Golec 2003, 120). Tamější grafitová keramika je dávána do souvislosti s podobně malým množstvím nalezené vekerzugské keramiky (Golec 2003, 121-122). Tato složka však „U Hájkova mlýna“ mikrosondážemi rozpoznána nebyla.

4) Přítomnost vlivů karpatské kotliny pozdního halštatu v tomto regionu byla v literatuře již několikrát zmíněna (Golec 2003, 105-107; Šabatová 2008). Přímých dokladů ve formě šperků a militarií však před nástupem masivního detektoringu nebylo mnoho. V po- sledních několika letech se takových nálezů objevuje relativně velké množství a to právě včetně záušnic (např. Zlínský kraj; autopsie autorů).

V případě lokality „U Hájkova mlýna“ je relativně neobvyklý vysoký počet kovových šperků, včetně naprosté absence typických trojhranných šipek.

5) Zajímavá je absence jakýchkoliv dokladů výroby textilií (tkalcovství - přesleny, závaží). Nálezy tohoto druhu jsou přitom v prrípadě trati „Sutny“ poměrně časté (Červená 2014, 64; Golec 2003, 129).

Určení funkce a celková interpretace areálu 
je značně problematická a je nutné zdůraznit, že by bylo vhodné doplnit spektrum nedestruktivních metod o několik zjištovacích sond, které by blíže specifikovaly povahu některých objektů (např. problematika lineárního ohrazení špice ostrožny, které mikrosondami nebylo možné jednoznačně rozlišit). Z hlediska získaného materiálu se jeví zjištěná lokalita jako více odlišná od lokalit situovaných na severní břeh. Je jisté, že některé odlišnosti jsou dány zcela rozdílným způsobem získávání dat. Na „Sutnách“ a „Vinohradech“ probíhal dlouhodobý systematický a záchranný výzkum, při němž nebyla nadložním vrstvám věnována větší pozornost. Naopak v případě trati „U Hájkova mlýna“ máme data především z těchto kontextů. Předkládané výsledky jsou tedy v mnohém doplňující.

Z hlediska rozdílných aspektů je nicméně nutné znovu zmínit umístění v krajině, absenci předmětů hospodářské činnosti, přítomnost grafitu v keramickém těstě a nálezy většího množství šperků (oproti „Sutnám“, „Vinohradům“ a jiným halštatským lokalitám).

$\mathrm{Na}$ základě těchto indicií můžeme tedy s velkou dávkou opatrnosti mluvit o specifické funkci nově zjištěného areálu v rámci halštatského mikroregionu.

\section{Závěr}

Systematický průzkum areálu v trati „U Hájkova mlýna“ (k. ú. Suchohrdly) přinesl zajímavá zjištění a umožnil zařazení lokality do systému sídelní struktury. Nedestruktivní nebo málo destruktivní metody byly založeno na mapování zahloubených struktur antropogenního původu a jejich vzorkování v pravidelné síti.

V zásadě můžeme konstatovat, že zjištění geofyzikální prospekce výrazně doplňují naše poznatky o lokalitě a plně korelují s poznatky dosaženými pomocí sítě mikrosond a detektorového průzkumu.
Sídelní aktivity se koncentrovaly především do severní části plošiny blízko k vodnímu toku. Pro halštatské období je v regionu tento jev typický. Z velké části se jedná o blíže nedefinovatelné sídlištní objekty a jeden výrobní.

Zajímavým zjištěním, které by mohlo dokládat určitou výlučnost areálu oproti nejbližšímu okolí, je dvojité liniové opevnění (pravděpodobně př́kop) na špici jedné $\mathrm{z}$ ostrožen. Potenciálně opevněný prostor je velmi malý ( 0,15 ha), pozdní halštat se vyznačuje ohrazováním drobných ostrožen a hřbetů (medián plochy výšinných areálu v halštatu pro jihozápadní Moravu je 1,25 ha). Geofyzikou a sondováním se uvnitř opevněného prostoru nepodařilo identifikovat ani žádné podpovrchové struktury. Nicméně v př́ípadě lehčích kůlových konstrukcí tento jev nemusí být zachytitelný.

Získaná keramika byla velmi fragmentární a neumožňuje rozsáhlou analýzu. Pouze na několika zlomcích bylo možné identifikovat původní tvar nádoby a výzdobu, která je pro typická pro pozdní halštat (HD1-HD2). Zajímavá je častá př́itomnost grafitu v keramickém těstě a naopak absence dokladů textilní výroby. V tomto směru se jedná o opačné zjištění oproti „Sutnám“ a „Vinohradům“.

Celkově bylo detektorem kovu zachyceno 8 předmětů, které lze téměř s jistotou datovat do průběhu halštatu (2 spony, 2, jehlice, 2 záušnice, zlomek bronzového náramku a bronzový slitek). Záušnice mají jisté paralely ve vekerzugské kultuře v Karpatské kotlině.

Vzhledem k přítomnosti pozdně halštatské keramiky, šperků, k podobné sídelní strategii a blízkosti dalších struktur lze areál Suchohrdly „U Hájkova mlýna“ začlenit do těšetického halštatského mikroregionu, do něhož náleží ještě plochy systematického a záchranného výzkumu na „Sutnách“, trat’ „Vinohrady“, prostor lokality „Starý zámek“ a „Deblínek (?)“. Všechny tyto areály spolu geograficky a kulturně úzce souvisí. 


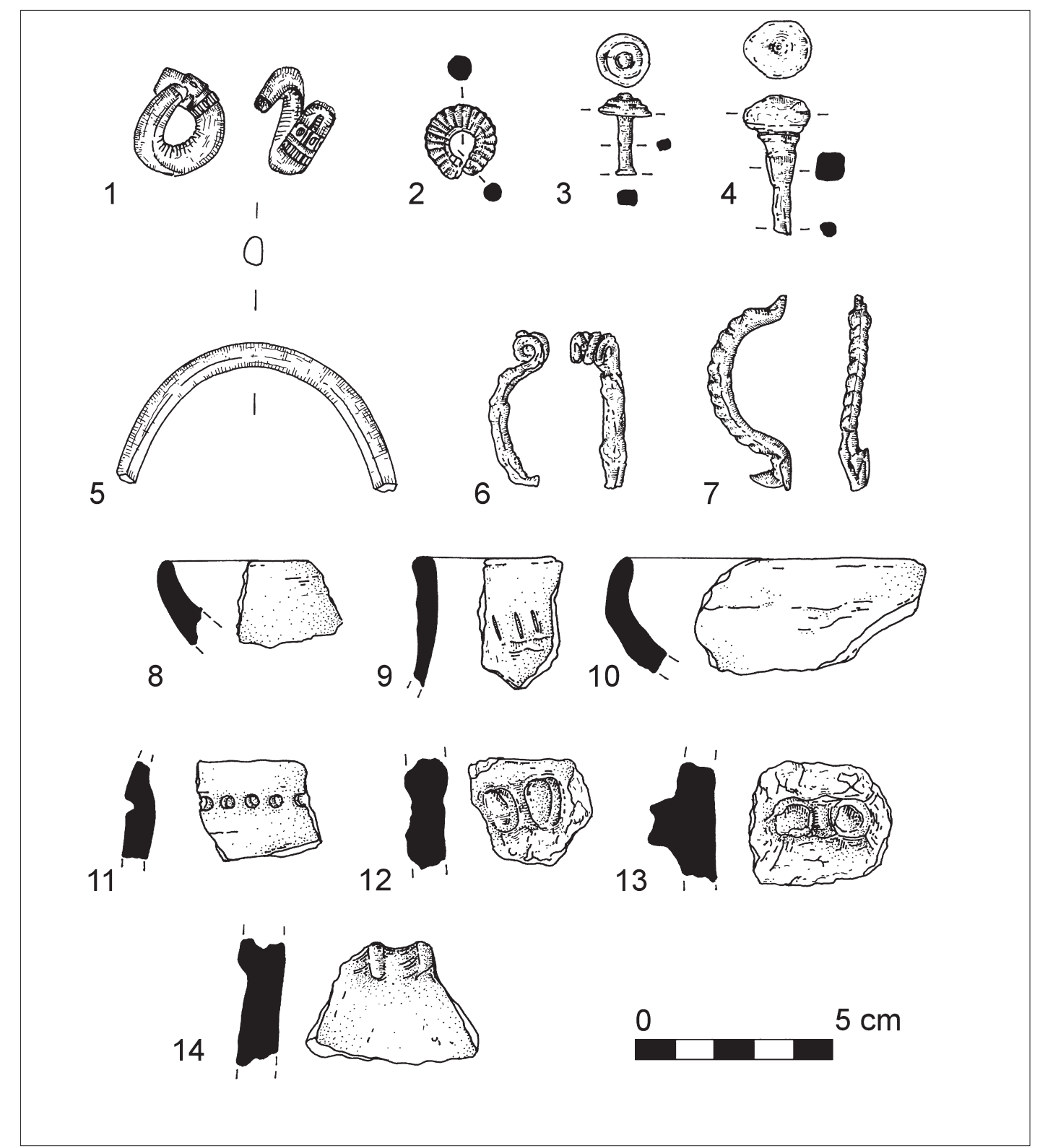

Obr. 9. Suchohrdly „U Hájkova mlýna”. Kovové artefakty a výběr z keramiky z mikrosond. Kresba Š. Trávníčková.

Fig. 9. Suchohrdly "U Hájkova mlýna". Metal artefacts and a selection of pottery from microprobes. Drawing by Š. Trávníčková. 
Poznání funkce a charakteru lokality je ztíženo formativními procesy, které lokalitu zjevně postihly. Jedná se především o masivní erozi povrchu, která se projevuje přítomností nápadných strží. Existence několika specifických prvků (příkop, výskyt šperků, absence klasických dokladů textilnictví, fragmentární keramika) není příliš charakteristická, co se týče intepre- tace klasického zemědělského sídliště, jak je tomu v případě zbytku mikroregionu. Více snad vyhovuje srovnání s halštatskými aktivitami na výšinném areálu „Starý zámek“. Mưžeme tedy s velkou dávkou opatrnosti mluvit o specifické funkci nově zjištěného areálu v rámci halštatského mikroregionu.

\section{Poznámky:}

1) <http://nahlizenidokn.cuzk.cz/> [cit. 2016-01-25]

\section{Literatura}

Beně̌, J. - Hrubý, P. - Kuna, M. 2004: Vyhledávání a vzorkování vrstev. In: Kuna, M. (ed.): Nedestruktivní archeologie, Praha, 353-378.

Bíško, R. 2011: Pravěké výšinné osídlení na JZ Moravě, rkp. magisterské práce ÚAM, Brno.

Bíško, R. - Milo, P. - Petřík, J. 2013: Průzkum hradiska Suchohrdly „Deblínek“ v povodí říčky Únanovky, Studia archeologica Brunensia 18/1, 39-49.

Bláha, J. 1977: Výsledky revize některých drobných středověkých opevnění v horním Podyjí, Archaeologia historica 2, 45-58.

Červená, K. 2014: Nově prozkoumané situace horákovského osídlení z polohy Těšetice-Kyjovice „Sutny“, rkp. bakalářské práce ÚAM, Brno.

Čižmářr, M. 1999: K poznání hradiska u Jaroměřic nad Rokytnou, okres Třebíč, Pravěk NŘ 9, 335-356.

Demek, J. - Mackovčin, P. a kol. 2006: Hory a nížiny. Zeměpisný lexikon ČR, Brno.

Erneé, M. 2008: Pravěké kulturní souvrství jako archeologický pramen. Památky archeologické Supplementum 20, Praha.

Goláňová, P. 2014: K použití a provenienci grafitu v časné době laténské na Moravě. In: Čižmářová, J. a kol. (eds.): Moravské křižovatky. Střední Podunají mezi pravěkem a historií, Brno, 133-141.

Golec, M. 2003: Těšetice-Kyjovice 6. Horákovská kultura v těšetickém mikroregionu, Brno.

Hutchinson, M. F. 1989: A new procedure for gridding elevation and stream line data with automatic removal of spurious pits, Journal of Hydrology 106, 211-232.
Hlava, M. 2008: Grafit v době laténské na Moravě, Památky archeologické XCIX, 189-258.

Hložek, M. a kol. 2003: Mikropetrografické rozbory halštatské grafitové keramiky z Těšetic „Suten“ a Traisentalu. In: Těšetice-Kyjovice 6. Horákovská kultura v těšetickém mikroregionu, Brno, 122-129.

Kuna, M. - Němcová, A. a kol. 2012: Výpověd' sídlištního odpadu, Praha.

Milo, P. 2013: Sídliská a sídliskové objekty na lokalite Těšetice-Kyjovice „Sutny“ z pohladu geomagnetického prieskumu. Studia archeologica Brunensia 18/1, 71-91.

John, J. 2002: O hustotě pozdně halštatských a časně laténských výšinných lokalit v jihozápadních Čechách. In: Neustupný, E. (ed.): Archeologie nenalézaného, Plzeň-Praha.

Novotná, M. - Novotný, B. 1990: Pravek Europy III, Bratislava.

Opravil, E. 1961: Vegetační poměry Znojemska v době halštatské. Acta Musei Moraviae, Scientiae geologicae 46, 81-99.

Parma, D. 2001: Předkeltské osídlení Hostýna I-II, rkp. magisterské práce ÚAM, Brno.

Petřík, J. - Petr, L. - Šabatová, K. - Doláková, N. Lukšíková, H. - Dohnalová, A. - Koptíková, L. Blaško, D. - Milo, P. 2015: Reflections of Prehistoric and Medieval human activities in floodplain deposits of the Únanovka Stream, South Moravia, Czech Republic, Zeitschrift für Geomorphologie, 393-412.

Podborský, V. 1965: Sídliště horákovské kultury u Bezkova, okres Znojmo, Sborník prací Filozofické fakulty brněnské univerzity E10, 135-152. 
Podborský, V. 1966: Halštatské osídlení Palliardiho hradiska u Vysočan, Sborník prací Filozofické fakulty brněnské univerzity E11, 128-131.

Podborský, V. 1970: Jihomoravská halštatská sídliště

I, Sborník prací Filozofické fakulty brněnské univerzity. E, Ǩada archeologicko-klasická, 7-102.

Podborský, V. 1972: Jihomoravská halštatská sídliště II, Sborník prací Filozofické fakulty brněnské univerzity E $17,5-54$.

Podborský, V. a kol. 2005: Pravěk mikroregionu potoka Těšetičky/Únanovky. K problematice pravěkých sociálních struktur, Brno.

Šabatová, K. 2007: Sídelní areál střední a mladší doby bronzové v Přáslavicích, rkp. dizertační práce ÚAM, Brno.

Šabatová, K. 2008: Suchohrdly (okr. Znojmo), Přehled výzkumů 49, 323-324, 335.

Šabatová, K. 2009: Suchohrdly (okr. Znojmo), Přehled výzkumů 50, 278.

Šabatová, K. 2010: Suchohrdly (okr. Znojmo), Přehled výzkumů 51, 338.

\section{Resume}

The vast forested area of Tvořihrázský les and its immediate neighbourhood capture the attention of archaeologists since the 1920s already. Some excavations have gradually been carried out here which proved that the area was intensively inhabited, not only during the Hallstatt Period (Vildomec 1954; Podborský 1972, 47; Šabatová 2011, 2013). During verification of a predictive model of hilltop localities, a new Hallstatt Period site was discovered on the right bank of the Unanovka Stream in the tract of land "U Hájkova mlýna" (cadastral district of Suchohrdly; Bíško 2011). This article is mainly targeted at presentation of results of a non-destructive or little destructive survey at the "U Hájkova mlýna" site (Fig. 1). Considering the narrow connection to the other Hallstatt Period sites in the vicinity, there is a possibility of comparison and a question of general inclusion into the micro-regional structure.

The "U Hájkova mlýna" site itself is situated on a distinct irregular plateau (amphitheatric sunken
Šabatová, K. 2011: Intenzivní studium osídlení v souvislých porostech na příkladu lesního území v mikroregionu říčky Únanovky, Sborník prací Filozofické fakulty brněnské univerzity M 16, 43-52.

Šabatová, K. 2013: Archeologické doklady lidských aktivit v prostoru Tvořihrázského lesa, Studia archeologica Brunensia 18/1, 21-38.

Trebsche, P. 2011: Eisenzeitliche Graphittonkeramik im mittleren Donauraum. In: Vorträge des 29. Niederbayerischen Archäologentages, Rahden/ Westf., 449-481.

Vildomec, V. 1954: Předhistorické opevnění u vesnice Suchohrdly u Znojma, Vlastivědný věstník moravský IX, 83-86.

Vokáč, M. 2004: Nové výšinné a opevněné lokality z eneolitu na jihozápadní Moravě. In: Lutovský, M. (ed.): Otázky neolitu a eneolitu našich zemí, Praha, 257-270.

Internetové zdroje:

<http://nahlizenidokn.cuzk.cz/> [cit. 2016-01-25]

step) on the right bank of the Unnanovka Stream at a height of 250-260 m ASL (relative superelevation ca. $30 \mathrm{~m}$ ). The whole complex is about $500 \mathrm{~m}$ long and $180 \mathrm{~m}$ wide.

With regard to the wooded landscape in the tract of land "U Hájkova mlýna", the otherwise wide spectrum of non-destructive methods was considerably depleted and it had to be enriched with some little destructive approaches (network of microprobes, magnetometric survey and metal detector survey).

Geophysical survey at the site identified numerous anomalies of various origin (Fig. 2). Many of them can be associated with prehistoric anthropogenic activities. On the resulting magnetogram we can observe ca. 70 anomalies, which can be interpreted as archaeological features. Regarding their variability from the ring-shaped and oval-shaped features through to irregular layouts, they represent a wide spectrum of settlement pits sized between 1 and $20 \mathrm{~m} 2$. Specific character and original function of these features are not known. Among important results of magnetometric survey is the localisation of 
linear anomalies on a projection of the spur above the Únanovka Stream (area B). But it cannot be said with certainty whether or not it is a fortification. Based on concentrations of ceramic fragments in individual segments of the area it is possible to localise several sunken structures of anthropogenic origin (Fig. 3). Microprobes in the area yielded pottery mainly from prehistoric times - the Late Hallstatt Period; the minor part of fragments can be dated to medieval and modern times. A great deal of Hallstatt Period pottery was tempered with graphite. Among ceramic forms we can recognise with certainty only fragments of large and small bowls with in-turned rim: group 31200 (after Dreslerová 1995). The other rims, regarding their shape and graphite content, may have belonged to pot-shaped and barrel-shaped vessels and other forms (Fig. 9). Constructions are evidenced by numerous finds of clay daub, which were mainly concentrated in the area of grid B (Fig. 5).

All the pottery obtained by microprobes was very fragmentary. This condition can be caused by several factors, which in principle influence the preservation of a vessel. It was not possible to identify any unit resembling the characteristics of an occupation layer. An important role in preservation of pottery is played by geology and geomorphology of the locality. The ground in the eastern part of the site is relatively even, in contrast to the western part of the plateau where the slope inclination varies around $7^{\circ}$. It is also possible to observe a difference in fragmentation index (high index represents large amount of small fragments with low weight). Whereas the concentrations with high index occur more frequently in the western part of the slope than in the eastern part, the situation with low index is rather opposite (Fig. 6). However, considerable fragmentariness can also be caused by some unspecified phenomena, which could not be paid more attention (e.g. character and function of features identified, material and type of firing in vessels, etc.).

Metal detector identified a total of 8 objects, which can almost certainly be dated to the Hallstatt Period ( 2 brooches, 2 pins, 2 lock-rings, fragment of a bronze bracelet, and a bronze bloom; Fig. 9). The lock-rings have some parallels in the Vekerzug Culture in the Carpathian Basin.

It is very important to determine which type of area is the "U Hájkova mlýna" site. The knowledge of function and character of the locality is complicated by formative processes which have evidently affected the locality. Among them mainly is a massive surface erosion resulting in conspicuous gorges. With regard to pottery decoration, the frequent occurrence of daub, and the general proximity of other Hallstatt components of classical settlement character (the sites of "Sutny" and "Vinohrady") it is possible to regard the site as a part of a tightly linked set of elements - localities of the Hallstatt microregion (Fig. 7). Regarding the material obtained, the locality identified appears to be more different from the localities situated on the northern bank, and the function of an agricultural-pastoral settlement site is rather not probable. Worth mentioning is particularly the presence of a linear fortification of the spur, absence of objects of economic activities, and presence of many personal ornaments (in comparison with "Sutny" and "Vinohrady", even though here a complex archaeological excavation has been carried out). The comparison with Hallstatt Period activities in the hilltop area of "Starý zámek" is maybe more relevant. We can thus speak with a great deal of caution about a specific function of the newly identified area within the Hallstatt microregion. 


\section{Mgr. Richard Bíško}

- Ústav archeologie a muzeologie, Filozofická fakulta, Masarykova univerzita, Arna Nováka 1, 60200 Brno rich.bisko@gmail.com

\section{Bc. Kateřina Červená}

- Ústav archeologie a muzeologie, Filozofická fakulta, Masarykova univerzita, Arna Nováka 1, 60200 Brno 382563@mail.muni.cz

\section{Dr. Peter Milo}

- Ústav archeologie a muzeologie, Filozofická fakulta, Masarykova univerzita, Arna Nováka 1, 60200 Brno 101090@mail.muni.cz

\section{Mgr. Jan Petřík}

- Ústav geologických věd, Prírodovědecká fakulta, Masarykova univerzita, Kotlářská 2, 61137 Brno jpazourek@email.cz 